\title{
Stress Analysis of Concrete Sections Under Service Load
}

\section{Brøndum-Nielsen, Troels}

Publication date:

1979

Document Version

Publisher's PDF, also known as Version of record

Link back to DTU Orbit

Citation (APA):

Brøndum-Nielsen, T. (1979). Stress Analysis of Concrete Sections Under Service Load. Technical University of Denmark, Department of Civil Engineering.

\section{General rights}

Copyright and moral rights for the publications made accessible in the public portal are retained by the authors and/or other copyright owners and it is a condition of accessing publications that users recognise and abide by the legal requirements associated with these rights.

- Users may download and print one copy of any publication from the public portal for the purpose of private study or research.

- You may not further distribute the material or use it for any profit-making activity or commercial gain

- You may freely distribute the URL identifying the publication in the public portal

If you believe that this document breaches copyright please contact us providing details, and we will remove access to the work immediately and investigate your claim 


\section{AFDELINGEN FOR BARENDE KONSTRUKTIONER}

DANMARKS TEKNISKE HOJSKOLE

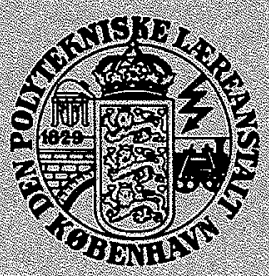

STRIGTURAI. RISEARCH LABORATORY

TRGHNIGAI UNINERITY OF DINMARK

Troels Brondum-Nielsen

STRESS ANALYSIS OF CONCRETE SEGTIONS UNDER SERVICE LOAD 
STRESS ANALYSIS OF CONCRETE

SECTIONS UNDER SERVICE LOAD

Reprint of paper published in the Journal of the American Concrete Institute, Proc. Vol. 76, No. 2, February, 1979. 


\section{ACI JOURNAL TECHNICAL PAPER}

Title no. $76-10$

\section{Stress Analysis of Concrete Sections Under Service Load}

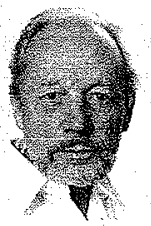

by Troels Brøndum-Nielsen

The stress analysis of concrete sections under service load is complicated by the interaction of shrinkage, creep, elastic strains of concrete and steel, and steel relaxation. Further complications arise in the case of partially prestressed concrete structures, with cracked cross sections under service load and with mixed reinforcement consisting of a combination of prestressed and nonprestressed reinforcement with individual mechanical properties and different effective depths. Combinations of sustained and instantaneous loads also complicate the analysis, whereas compound bending is easily taken into account. An analysis is suggested covering these problems in cases of symmetrical bending.

Keywords: bending; cracking (fracturing); creep properties; fatigue (materials); loads (forces): partial prestressing: prestressed concrete; prestressing steels; reinforced concrete; shrinkage; strains; stress analysis; structural analysis.

Received Apr. 11, 1978, and reviewed under Institute publication policies. Copyright (C) 1979. American Concrete Institute. All rights reserved, including the making of copies unless permission in writing is obtained from the copyright proprietor. Discussion closes May 1, 1979. 
ACI member Troels Brøndum-Nielsen, Dr.techn, is professor in theory of structures at the Structural Research Laboratory, Technical University of Denmark. He is a member of Conseil d'Administration du Comité Euro-International du Béton and of the Danish Academy of Technical Sciences and vice-president of Fédération Internationale de la Précontrainte.

\section{EQUILIBRIUM CONDITIONS}

The concrete tensile strength is neglected. Under service load plane cross-sections are assumed to remain plane and concrete stresses are assumed to be proportional to the corresponding concrete strains exclusive of shrinkage strain.

For the concrete, compressive stresses, $\sigma_{c}$, are taken as positive and the shrinkage strain, $\varepsilon_{c s}$, corresponding to reduction in length is taken as positive. For ${ }^{c s}$ the reinforcement, tensile stresses and strains corresponding to elongation are taken as positive.

For the case of an arbitrary cross-section, sustained pure uniaxial bending and same effective depths, $d$, of both types of reinforcement (Fig. 1), moment equilibrium with respect to the reinforcement requires:

$$
M=\frac{\sigma_{c}}{\beta d} \int_{0}^{\beta d} y b(y)[(1-\beta) d+y] d y=\frac{\sigma_{c}}{\beta d}[S(1-\beta) d+I]
$$

with the notation:

$y:$ distance above neutral axis

$b(y)$ : width of cross-section at distance $y$ above neutral axis

M: sustained bending moment. Positive sign corresponds to compression in top fibres

S: first moment of area of compressed concrete section with respect to the neutral axis

$\sigma_{c}$ : maximum concrete compressive stress

d: effective depth

Bd: depth of neutral axis

I: second moment of area of compressed concrete section with respect to the neutral axis

The neutral axis is the line at which the concrete stresses are equal to zero, but where, due to shrinkage, the concrete strains are not necessarily equal to zero.

Equilibrium in the axial direction requires: 


$$
A_{s} \varepsilon_{s} E_{s}+A_{p} \sigma_{p}-\frac{\sigma_{c}}{\beta d} \int_{0}^{\beta d} y b(y) d y=A_{s} \varepsilon_{s} E_{s}+A_{p} \sigma_{p}-\sigma_{c} \frac{S}{\beta d}=0
$$

with the notation:

\footnotetext{
$A_{S}$ : cross-sectional area of non-prestressed steel

$\varepsilon_{s}$ : strain in non-prestressed steel

$E_{S}$ : strain modulus of non-prestressed steel

$A_{\mathrm{p}}$ : cross-sectional area of prestressing steel

$\sigma_{p}$ : tensile stress in prestressing steel
}

\section{RELAXATION}

The relaxation of the prestressing steel is taken into account by assuming a stress-strain relationship for constant, sustained load giving $\sigma_{\mathrm{p}}$ as a function of the corresponding strain $\varepsilon_{\mathrm{p}}$ at

$$
\sigma_{p}=f\left(\varepsilon_{p}\right)
$$

\section{CREEP}

For the concrete, the following assumptions are made both for the initial strain and for the creep strains created by sustained stresses (shrinkage strain not included):

The strain is assumed to be proportional to the corresponding concrete stress.

Strain contributions due to stress contributions applied at different times are assumed to be additive (law of superposition).

These assumptions are illustrated in Fig. 2, where the following notation is used:

$$
\begin{aligned}
& { }_{c i}: \text { instantaneous concrete strain } \\
& { }_{c c}: \text { concrete strain due to creep } \\
& { }_{c c}: \begin{array}{l}
\text { strain modulus of concrete for } \\
\text { instantaneous load }
\end{array} \\
& E_{c g}: \begin{array}{l}
\text { effective strain modulus of concrete } \\
\text { for sustained load }
\end{array}
\end{aligned}
$$

\section{COMPATIBILITY}

Compatibility requires (Fig. 1):

$$
\Delta \varepsilon_{p}+\varepsilon_{c s}=\varepsilon_{s}+\varepsilon_{c s}=\frac{\sigma_{c}}{E_{c g}} \frac{1-\beta}{\beta}
$$


with the notation:

$$
\begin{aligned}
\Delta \varepsilon_{\mathrm{p}}: & \text { strain increment in prestressing } \\
& \text { steel over pretensioning strain, } \varepsilon_{\text {po }} \\
\varepsilon_{\mathrm{po}}: & \text { strain in prestressing steel when the } \\
& \text { total strain (including shrinkage strain) } \\
& \text { in the concrete and in the non-prestressed } \\
& \text { reinforcement is equal to zero. } \\
\varepsilon_{\mathrm{cs}}: & \text { the shrinkage strain that would occur in the } \\
& \text { concrete if its stresses remained equal to } \\
& \text { zero and its temperature remained unchanged }
\end{aligned}
$$

The total strain in the prestressing steel is:

$$
\varepsilon_{p}=\varepsilon_{\text {po }}+\Delta \varepsilon_{p}
$$

\section{ANALYSIS PROCEDURE}

The results of the above derivation may conveniently be presented in the following form and sequence:

Eq. (1):

$$
\sigma_{c}=\frac{M \beta d}{I+S(1-\beta) d}
$$

Eq. (4):

$$
\varepsilon_{s}=\frac{{ }_{c}^{\sigma}}{E_{c g}} \frac{1-\beta}{\beta}-\varepsilon_{c s}
$$

Eqs. (5) and (4):

$$
\varepsilon_{p}=\varepsilon_{p o}+\varepsilon_{s}
$$

Eq. (3):

$$
\sigma_{\mathrm{p}}=\mathrm{f}\left(\varepsilon_{\mathrm{p}}\right)
$$

Introducing:

$$
g(\beta)=A_{s} E_{s} \varepsilon_{s}+A_{p} \sigma_{p}-\sigma_{c} \frac{S}{\beta d}
$$

Eqs. (2) and (10) yield:

$$
g(\beta)=0
$$

For an estimated value of $\beta$, the corresponding value of $\mathrm{g}(\beta)$ may be calculated by successive substitution in Eqs. (6) to (10), and the $\beta$ value can then be adjusted so as to satisfy Eq. (11) with sufficient accuracy.

If two values $g_{1}$ and $g_{2}$ of $g(\beta)$ have been calculated 
corresponding to the $\beta$ values $\beta_{1}$ and $\beta_{2}$, linear interpolation or extrapolation leads to the following improved $\beta$ value:

$$
\beta_{i}=\frac{g_{1} \beta_{2}-g_{2} \beta_{1}}{g_{1}-g_{2}}
$$

The method is suitable for programmable pocket calculators.

\section{EFFECTIVE DEPTH}

If the effective depth $d_{p}$ of the prestressed reinforcement deviates from that of the non-prestressed reinforcement, $d_{s}$, an equivalent value

$$
d=\frac{A_{p} \sigma_{p} d_{p}+A_{s} \sigma_{s} d_{s}}{A_{p} \sigma_{p}+A_{s} \sigma_{s}}
$$

may be substituted for $d$ with estimated values of $\sigma_{p}$ and $\sigma_{s}$, which can be corrected at each step of the iteration.

In this case Eqs. (4), (7) and (8) should be modified as follows:

Eq. (4):

$$
\begin{aligned}
& \varepsilon_{s}+\varepsilon_{c s}=\frac{{ }_{c}{ }_{c}}{E_{c g}}\left(\frac{d_{s}}{\beta d}-1\right) \\
& \Delta \varepsilon_{p}+\varepsilon_{c s}=\frac{{ }_{c}}{E_{c g}}\left(\frac{d_{p}}{\beta d}-1\right)
\end{aligned}
$$

Eq. (7):

$$
\begin{aligned}
& \varepsilon_{s}=\frac{\sigma_{C}}{E_{c g}}\left(\frac{d_{s}}{\beta d}-1\right)-\varepsilon_{c s} \\
& \Delta \varepsilon_{p}=\frac{\sigma_{C}}{E_{c g}}\left(\frac{d_{p}}{\beta d}-1\right)-\varepsilon_{c s}
\end{aligned}
$$

Eq. (8):

$$
\varepsilon_{\mathrm{p}}=\varepsilon_{\mathrm{po}}+\Delta \varepsilon_{\mathrm{p}}
$$

As the iteration is extended to cover variations of both $\beta$ and $d$, the interpolation according to Eq. (12) may be suitably modified so as to apply to the product $\beta d$ of $\beta$ and $d$, i.e., if two values $g_{1}$ and $g_{2}$ of $g(\beta)$ have been calculated corresponding to the $\beta d^{1}$ values $(\beta d)_{1}$ and $(\beta d)_{2}$, linear interpolation or extrapolation leads to the following improved $\beta \mathrm{d}$ value:

$$
(\beta d)_{i}=\frac{g_{1}(\beta d)_{2}-g_{2}(\beta d)_{1}}{g_{1}-g_{2}}
$$




\section{COMPOUND BENDING}

In the case of compound bending corresponding to a normal force $\mathrm{N}$, which is taken as positive when compressive, and which acts in the line of symmetry with the eccentricity $e_{p}$ with respect to the reinforcement, this is equivalent to a pure bending moment

$$
\mathrm{M}=\mathrm{Ne}_{\mathrm{p}}
$$

plus an increase in the prestressing force from $A_{p} \sigma_{p}$ to $A_{p} \sigma_{p}+$ N. $e_{p}$ is taken as positive when $N$ is located on the same side of the reinforcement as the compression zone.

If $d_{p}$ deviates from $d_{s}, e_{p}$ is taken as the distance from $N$ to the resultant of the stresses in both types of reinforcement, i.e. to the point located at a distance d from the most compressed fibre. The distance $d$ is given by Eq. (13).

The method thus also covers symmetric compound bending.

\section{T-SECTIONS}

For T-sections with a form as shown in Fig. 3 and for $\beta d>h$ :

$$
\begin{aligned}
& S=\frac{1}{2} b(\beta d)^{2}-\frac{1}{2}\left(b-b_{0}\right)(\beta d-h)^{2} \\
& I=\frac{1}{3} b(\beta d)^{3}-\frac{1}{3}\left(b-b_{0}\right)(\beta d-h)^{3}
\end{aligned}
$$

\section{INSTANTANEOUS LOADS}

The above stress analysis also covers the case of an instantaneous load, for instance, the situation immediately after tensioning of the tendons. In such cases, relaxation and creep do not occur. The following two modifications will consequently have to be introduced:

Eqs. (3) and (9) should read:

$$
\sigma_{\mathrm{p}}=\mathrm{E}_{\mathrm{p}} \varepsilon_{\mathrm{p}}
$$

where $E_{p}$ denotes the strain modulus of the prestressing steel.

The strain modulus $E_{C g}$ in Eqs. (4) and (7) should be substituted by the strain modulus, $E_{c q}$, corresponding to instantaneous stress variations.

\section{COMBINATIONS OF SUSTAINED AND INSTANTANEOUS LOADS}

The prestress and the dead load represent sustained load contributions. Consequently, instantaneous load contributions usually occur as an addition to a sustained load.

The stress analysis of such load combinations can be per- 
formed by a fictitious, instantaneous elimination of all concrete stresses from the sustained load fictitious, instantaneous neutralization).

The sustained load corresponds to a normal force $\mathrm{N}_{\mathrm{g}}$ with the eccentricity $e_{p g}$ with respect to the reinforcement. ${ }^{2}$ This includes the special - but common - case of pure bending ( $\mathrm{N}_{\mathrm{g}}=$ 0 , e e $\mathrm{pg}=\infty)$. The instantaneous load contribution changes the normal force $\mathrm{Ng}_{\mathrm{g}}$ with eccentricity $\mathrm{e}_{\mathrm{pg}}$ to $\mathrm{N}_{\mathrm{q}}$ with eccentricity $e_{p q}$ with respect to the reinforcement.

The corresponding stresses are found by an analysis analogous to that indicated above, (Eqs. (6) to (16)), with the following modifications:

To the stress contributions from the load $\mathrm{N}_{\mathrm{q}}$ should be added the neutralized stresses in the non-prestressed and prestressed steel:

$$
\sigma_{s n}=E_{s}\left[\varepsilon_{s}(1-n)-n \varepsilon_{c s}\right]
$$

and

$$
\underset{p n}{\sigma}=\underset{p}{\sigma}-\chi E_{p}\left(\varepsilon_{s}+\varepsilon_{c s}\right)
$$

with the notation:

$$
x=\frac{E_{c g}}{E_{c q}}
$$
lows:

If $d_{p}$ deviates from $d_{s}$, Eq. (19) should be modified as fol-

$$
\sigma_{p n}=\sigma_{p}-\chi E_{p}\left(\Delta \varepsilon_{p}+\varepsilon_{c s}\right)
$$

\section{FATIGUE}

The suggested stress analysis is applicable for investigation of safety against fatigue. In this case, the average normal force over an extended period should be substituted for $\mathrm{Ng}$.

For $\mathrm{N}_{\mathrm{q}}$, two values should be considered, corresponding to the upper and lower load extremes, which occur a given number of times.

The resulting maximum and minimum stresses in the concrete, in the prestressing steel and in the non-prestressed steel can then be compared with the corresponding results of fatigue tests for these materials so as to check whether there is sufficient safety against fatigue. 


\section{CEB-FIP RELAXATION FORMULA}

The 1970 edetion of the CEB-FIP Recommendations* suggested a relaxation formula which can be expressed as follows:

For $\sigma_{p o} \leqq \sigma_{p 1}\left(\sigma_{\text {po }}\right.$ denoting the initial value of $\left.\sigma_{p}\right)$ : No relaxation:

$$
\sigma_{p}=\sigma_{p o}=E_{p} \varepsilon_{p} \text { for } \varepsilon_{p} \leqq \frac{\sigma_{p}}{E_{p}}=\varepsilon_{1}
$$

For ${ }_{\mathrm{p} 1} \leqq \sigma_{\mathrm{p}} \leqq \sigma_{\mathrm{p} 2}:$

Relaxation:

$$
\Delta \sigma_{\mathrm{p}}=\mathrm{E}_{\mathrm{r}}\left(\varepsilon_{\mathrm{p}}-\varepsilon_{1}\right)^{2}
$$

where $E_{r}$ is a constant. The stress remaining after relaxation is

$$
\sigma_{p}=E_{p} \varepsilon_{p}-\Delta \sigma_{p}=E_{p} E_{p}-E_{r}\left(\varepsilon_{p}-\varepsilon_{1}\right)^{2}
$$

Eqs. (21) and (22):

$$
E_{r}=\frac{\Delta \sigma_{p} E_{p}^{2}}{\left(\sigma_{p o}-\sigma_{p 1}\right)^{2}}
$$

If $\Delta \sigma_{p}$ is known for a given value of $\sigma_{p o}, E_{r}$ can be calculated by ${ }_{\text {Eq. }}(23 a)$ :

NUMERICAL EXAMPLE NO. 1

T-section (Fig. 3).

$$
\begin{aligned}
& \mathrm{b}=1.2 \mathrm{~m} \\
& b_{\mathrm{o}}=0.2 \mathrm{~m} \\
& \mathrm{~h}=0.1 \mathrm{~m} \\
& \mathrm{~d}=0.5 \mathrm{~m} \\
& A_{s}=10^{-3} \mathrm{~m}^{2} \\
& A_{\mathrm{p}}=10^{-3} \mathrm{~m}^{2} \\
& \mathrm{E}_{\mathrm{cg}}=10^{4} \cdot \mathrm{MPa} \\
& \mathrm{E}_{\mathrm{s}}=2.1 \cdot 10^{5} \mathrm{MPa}
\end{aligned}
$$

* Comité Européen du Béton - Fédération Intexnationale de la Précontrainte: International recommendations for the design and construction of concrete structures. June 1970: FIP Sixth Congress, Prague, English edition, p. 25. 


$$
\begin{aligned}
& \varepsilon_{p o}=0.004 \\
& \varepsilon_{C S}=0.0002
\end{aligned}
$$

For instantaneous strain variations the strain modulus of the prestressing steel is

$$
E_{p}=2.1 \cdot 10^{5} \mathrm{MPa}
$$

The characteristic strength of the prestressing steel is

$$
\begin{aligned}
& f_{\mathrm{ptk}}=1700 \mathrm{MPa} \\
& \sigma_{\mathrm{p} 1}=0.4 \mathrm{f}_{\mathrm{ptk}} * \\
& \varepsilon_{1}=\frac{\sigma_{\mathrm{p} 1}}{E_{\mathrm{p}}}=\frac{0.4 \cdot 1700}{2.1 \cdot 10^{5}}=0.00324 \\
& \sigma_{\mathrm{p} 2}=0.75 \mathrm{f}_{\mathrm{ptk}} \\
& \varepsilon_{2}=\frac{\sigma_{\mathrm{p} 2}}{\mathrm{E}_{\mathrm{p}}}=\frac{0.75 \cdot 1700}{2.1 \cdot 10^{5}}=0.00607
\end{aligned}
$$

For $\underset{\text { po }}{\sigma}=\sigma_{\mathrm{p} 2}: \quad \Delta \sigma_{\mathrm{p}}=0.15 \sigma_{\mathrm{p} 2}$

Eq. (23a):

$$
E_{r}=\frac{0.15 \cdot 0.75 \cdot 1700\left(2.1 \cdot 10^{5}\right)^{2}}{(0.75-0.4)^{2} \cdot 1700^{2}}=23.82 \cdot 10^{6} \mathrm{MPa}
$$

Eqs. (21) - (23):

For $\varepsilon_{p} \leqq 0.00324:$

$$
\sigma_{p}=2.1 \cdot 10^{5} \varepsilon_{p}
$$

For

$$
\begin{aligned}
& 0.00324 \leqq \varepsilon_{p} \leqq 0.00607: \\
& \sigma_{p}=2.1 \cdot 10^{5} \varepsilon_{p}-23.8 \cdot 10^{6}\left(\varepsilon_{p}-0.00324\right)^{2}
\end{aligned}
$$

or

$$
\underset{p}{\sigma}=364000 \varepsilon p-23.8 \cdot 10^{6} \varepsilon_{p}^{2}-250
$$

* Some of the numerical values deviate from those suggested in the CEB-FIP Recommendations. 
where the unit for $\sigma_{p}$ is MPa. The corresponding stress-strain relationship is illustrated in Fig. 4.

The stress analysis will be carried out for the case of pure bending corresponding to a sustained bending moment $M=0.5$ MNm.

Eqs. (15) and (16):

$$
\begin{aligned}
& S=0.15 \beta^{2}-\frac{1}{8}(\beta-0.2)^{2} \\
& I=0.05 \beta^{3}-\frac{1}{24}(\beta-0.2)^{3}
\end{aligned}
$$

Eq. (10):

$$
g(\beta)=210 \varepsilon_{S}+10^{-3} \sigma_{p}-\sigma_{C} \frac{2 S}{\beta}
$$

The calculation is illustrated in Table 1.

If the same bending moment were applied at the time of tensioning the tendons, then the initial stress in the prestressing steel would be $972 \mathrm{MPa}$. This is found by an analogous analysis in which shrinkage, creep and relaxation are neglected. The loss of prestress is thus $20 \mathrm{MPa}$.

If only the creep is taken into account, but not shrinkage and relaxation, an analogous analysis leads to a stress of $988 \mathrm{MPa}$ in the prestressing steel. The corresponding strain is 0.00471. If interaction were neglected, the relaxation would reduce the stress to $936 \mathrm{MPa}$ according to Eq. (9a), and the shrinkage strain would reduce this stress to $894 \mathrm{MPa}$, corresponding to a total loss of prestress of $78 \mathrm{MPa}$ instead of $20 \mathrm{MPa}$. This illustrates the considerable errrors that are introduced by neglecting the interaction of shrinkage, creep and relaxation.

\section{NUMERICAL EXAMPLE NO. 2}

For the cross-section treated in Numerical Example No. 1, the sustained bending moment $M=0.5 \mathrm{MNm}$ is assumed to increase suddenly to $0.6 \mathrm{Mnm}$.

The value of $x$ in Eqs. (18)-(20) is taken as:

$$
n=0.3
$$

Eq. (18):

$$
\begin{aligned}
& \sigma_{\text {sn }}=2.1 \cdot 10^{5}[0.000820(1-0.3)-0.3 \cdot 0.0002] \\
& \sigma_{\text {sn }}=107.9 \mathrm{MPa}
\end{aligned}
$$


$\mathrm{Eq} \cdot(19)$

$$
\begin{aligned}
& \stackrel{\sigma}{p n}^{\sigma}=952-0.3 \cdot 2.1 \cdot 10^{5}(0.000820+0.0002) \\
& { }_{p n}=888 \mathrm{MPa}
\end{aligned}
$$

For both types of reinforcement the instantaneous strain and stress increments to be added to the neutralized values are:

$$
\Delta \varepsilon_{\mathrm{s}}=\Delta \varepsilon_{\mathrm{p}}=\frac{{ }_{\mathrm{C}}}{\mathrm{E}_{\mathrm{cq}}} \frac{1-\beta}{\beta}=\frac{0.3 \sigma_{\mathrm{c}}}{10^{4}} \frac{1-\beta}{\beta}
$$

and

$$
\Delta \sigma_{\mathrm{S}}=\Delta \sigma_{\mathrm{P}}=\mathrm{E}_{\mathrm{S}} \Delta \varepsilon_{\mathrm{S}}=\mathrm{E}_{\mathrm{p}} \Delta \varepsilon_{\mathrm{p}}=2.1 \cdot 10^{5} \Delta \varepsilon_{\mathrm{S}}
$$

The total stresses in the two types of reinforcement are:

and

$$
\sigma_{\mathrm{s}}=\sigma_{\mathrm{sn}}+\Delta \sigma_{\mathrm{s}}=107.9+\Delta \sigma_{\mathrm{s}}
$$

$$
\sigma_{\mathrm{p}}=\underset{\mathrm{pn}}{\sigma}+\Delta \sigma_{\mathrm{S}}=888+\Delta \sigma_{\mathrm{S}}
$$

The equilibrium condition according to Eqs. (10) and (11) requires:

$$
g(\beta)=A_{s} \sigma_{s}+A_{p} \sigma_{p}-\sigma_{c} \frac{S}{\beta d}=10^{-3}\left(\sigma_{s}+\sigma_{p}\right)-\sigma_{c} \frac{S}{0.5 \beta}=0
$$

The calculation is illustrated in Table 2. In this case the interpolation value $\beta_{i}=0.369$ is only used as a guide. A comparison with the values in Table 1 suggests that a slightly lower value should be estimated.

If the increase in the bending moment had had the character of a sustained load instead, then the stresses would have been: $\sigma_{\mathrm{c}}=13.41 \mathrm{MPa}, \sigma_{\mathrm{s}}=309 \mathrm{MPa}$ and $\sigma_{\mathrm{p}}=1029 \mathrm{MPa}$. The differences are most important in connexiôn with calculations of deformations or safety against fatigue.

\section{NUMERICAL EXAMPLE NO. 3}

This example illustrates the analysis for a case where the effective depth $d_{p}$ of the prestressed reinforcement deviates from that of the non-prestressed reinforcement, $d_{s}$. The crosssection and all parameters are the same as in the numerical examples Nos. 1 and 2 with the sole difference that $d_{s}$ is taken as equal to $0.6 \mathrm{~m}$.

Eqs. (15) and (16):

$$
\begin{aligned}
& S=0.6(\beta d)^{2}-0.5(\beta d-0.1)^{2} \\
& I=0.4(\beta d)^{3}-\frac{1}{3}(\beta d-0.1)^{3}
\end{aligned}
$$


Eq. (7a):

$$
\begin{aligned}
& \varepsilon_{s}=\frac{\sigma_{c}}{E_{c g}}\left(\frac{d_{s}}{\beta d}-1\right)-\varepsilon_{c s} \\
& \sigma_{s}=2.1 \cdot 10^{5}\left[\frac{\sigma_{c}}{10^{4}}\left(\frac{0.6}{\beta d}-1\right)-0.0002\right] \\
& \sigma_{s}=21\left[\sigma_{c}\left(\frac{0.6}{\beta d}-1\right)-2\right]
\end{aligned}
$$

Eq. (7.b):

$$
\Delta \varepsilon_{p}=\frac{\sigma_{c}}{10^{4}}\left(\frac{0.5}{\beta d}-1\right)-0.0002
$$

Eqs. (10) and (2):

$$
g(\beta)=10^{-3}\left(\sigma_{s}+\sigma_{p}\right)-\sigma_{c} \frac{S}{\beta d}=0
$$

The calculation is illustrated in Table 3.

The following values corresponding to $g(\beta)=0$ are found by interpolating between the values of the last two columns:

$$
\begin{aligned}
\sigma_{\mathbf{c}} & =9.82 \mathrm{MPa} \\
\sigma_{\mathbf{s}} & =182 \mathrm{MPa} \\
\sigma_{\mathbf{p}} & =910 \mathrm{MPa} \\
\Delta_{\mathrm{\varepsilon}} & =0.000527
\end{aligned}
$$

Eq. (18):

$$
\sigma_{\text {sn }}=182(1-0.3)-2.1 \cdot 10^{5} \cdot 0.3 \cdot 0.0002=115 \mathrm{MPa}
$$

Eq. (19a):

$$
\sigma_{\mathrm{pn}}=910-0.3 \cdot 2.1 \cdot 10^{5}(0.000527+0.0002)=864 \mathrm{MPa}
$$

Eqs. (24), (9b), (7a) and (7c) for $\varepsilon_{c s}=0$

$$
\begin{aligned}
\sigma_{s} & =\sigma_{s n}+E_{s} \frac{\sigma_{c}}{E_{c q}}\left(\frac{d_{s}}{\beta d}-1\right)=115+2.1 \cdot 10^{5} \frac{0.3 \sigma_{c}}{10^{4}}\left(\frac{0.6}{\beta d}-1\right) \\
& =115+6.3 \sigma_{c}\left(\frac{0.6}{\beta d}-1\right) \\
\sigma_{p} & =864+6.3 \sigma_{c}\left(\frac{0.5}{\beta d}-1\right)
\end{aligned}
$$


The calculation is illustrated in Table 4.

The following values corresponding to $g(\beta)=0$ are found by interpolating between the values of the last two columns:

$$
\begin{aligned}
& \sigma_{c}=13.33 \mathrm{MPa} \\
& \sigma_{s}=\underline{281} \mathrm{MPa} \\
& \sigma_{p}=\underline{989} \mathrm{MPa}
\end{aligned}
$$

\section{CONCLUSION}

The suggested stress analysis of concrete sections under service load takes into account the interaction of the relevant physical properties such as creep, shrinkage, relaxation, etc. It is deemed useful for calculating deformations, crack widths, safety against fatigue, etc. As the analysis covers the general case of partially prestressed cross-sections cracked under service load, it includes the special cases of fully prestressed sections and reinforced concrete sections without prestress.

\section{RECOMMENDATIONS}

In reinforced and prestressed concrete cross-sections, variations in stress due to creep, shrinkage, relaxation, etc. are usually found simply by adding the individual contributions, which means that the interaction between them is neglected. The suggested analysis takes this interaction into account and thus avoids an inaccuracy that can lead to considerable exrors. 
TABLE 1 - Stress Analysis for Sustained Load

\begin{tabular}{|c|c|c|c|c|c|c|}
\hline$\beta$ & & & 1.0 & 0.5 & 0.518 & 0.510 \\
\hline & Unit & Eq. & & & & \\
\hline $\mathrm{S}$ & $\mathrm{m}^{3}$ & $15 \mathrm{a}$ & 0.070 & 0.02625 & 0.02761 & 0.02700 \\
\hline$\sigma_{\mathrm{c}}$ & $\mathrm{MPa}$ & $16 \mathrm{a}$ and 6 & 8.72 & 10.70 & 10.56 & 10.62 \\
\hline$\varepsilon_{\mathrm{S}}$ & & 7 & -0.0002 & 0.000870 & 0.000783 & $\underline{0.000820}$ \\
\hline$\varepsilon_{\mathrm{p}}$ & & 8 & 0.0038 & 0.00487 & 0.00478 & 0.00482 \\
\hline$\sigma_{\mathrm{p}}$ & $\mathrm{MPa}$ & $9 \mathrm{a}$ & 790 & 958 & 946 & $\underline{952}$ \\
\hline $\mathrm{g}(\beta)$ & $\mathrm{MN}$ & $10 \mathrm{a}$ & -0.4700 & 0.01720 & -0.01529 & -0.00027 \\
\hline$\beta_{\mathrm{i}}$ & & 12 & & 0.518 & 0.510 & 0.510 \\
\hline
\end{tabular}

TABLE 2 - Stress Analysis for Combination of Sustained and Instantaneous Loads

\begin{tabular}{|c|c|c|l|l|l|}
\hline$\beta$ & & & 0.4 & 0.3 & 0.360 \\
\hline $\mathrm{S}$ & $\mathrm{m}^{3}$ & $15 \mathrm{a}$ & 0.01900 & 0.01225 & 0.01624 \\
\hline$\sigma_{\mathrm{c}}$ & $\mathrm{MPa}$ & $16 \mathrm{a}$ and 6 & 14.00 & 16.08 & 14.68 \\
\hline$\Delta \mathrm{s}_{\mathrm{s}}$ & & $7 \mathrm{c}$ & 0.000630 & 0.001126 & 0.000783 \\
\hline$\Delta \sigma_{\mathrm{S}}$ & $\mathrm{MPa}$ & $9 \mathrm{~b}$ & 132.3 & 236.5 & 164.4 \\
\hline$\sigma_{\mathrm{s}}$ & $\mathrm{MPa}$ & 24 & 240.2 & 344.4 & 272.3 \\
\hline $\begin{array}{c}\sigma_{\mathrm{p}} \\
\mathrm{g}(\beta)\end{array}$ & $\mathrm{MPa}$ & 25 & 1020 & 1124 & 1052 \\
\hline$\beta_{i}$ & & 26 & -0.0698 & +0.1552 & -0.000162 \\
\hline
\end{tabular}


TABLE 3 - Stress Analysis for Sustained Load

\begin{tabular}{|c|c|c|l|l|l|}
\hline$\beta$ & & & 0.55 & 0.556 & 0.557 \\
\hline $\mathrm{d}$ & $\mathrm{m}$ & & & & \\
\hline$\beta \mathrm{d}$ & $\mathrm{m}$ & & 0.52 & 0.517 & 0.517 \\
\hline $\mathrm{S}$ & $\mathrm{m}^{3}$ & $15 \mathrm{~b}$ & 0.0318 & 0.0319 & 0.0321 \\
\hline$\sigma_{\mathrm{c}}$ & $\mathrm{MPa}$ & $16 \mathrm{~b} \&$ & 9.76 & 9.83 & 9.80 \\
\hline$\sigma_{\mathrm{s}}$ & $\mathrm{MPa}$ & 27 & 183 & 183 & 181 \\
\hline$\Delta \varepsilon_{\mathrm{p}}$ & & 28 & 0.000530 & 0.000530 & 0.000521 \\
\hline$\varepsilon_{\mathrm{p}}$ & & $8 \mathrm{a}$ & 0.00453 & 0.00453 & 0.00452 \\
\hline$\sigma_{\mathrm{p}}$ & $\mathrm{MPa}$ & $9 \mathrm{a}$ & 911 & 911 & 909 \\
\hline $\mathrm{g}(\beta)$ & $\mathrm{MN}$ & $26 \mathrm{a}$ & 0.0088 & 0.0014 & -0.0023 \\
\hline $\mathrm{d}$ & $\mathrm{m}$ & 13 & 0.517 & 0.517 & 0.517 \\
\hline$(\beta \mathrm{d})$ & $\mathrm{m}$ & $12 \mathrm{a}$ & & 0.287 & \\
\hline
\end{tabular}

TABLE 4 - Stress Analysis for Combination of Sustained and Instantaneous Loads

\begin{tabular}{|c|c|c|c|c|c|}
\hline$\beta$ & & & 0.39 & 0.387 & 0.386 \\
\hline $\mathrm{d}$ & $\mathrm{Unit}$ & $\mathrm{Eq}$. & & & \\
\hline$\beta \mathrm{d}$ & $\mathrm{m}$ & & 0.52 & 0.522 & 0.522 \\
\hline $\mathrm{S}$ & $\mathrm{m}^{3}$ & $15 \mathrm{~b}$ & 0.01942 & 0.01928 & 0.01914 \\
\hline$\sigma_{\mathrm{c}}$ & $\mathrm{MPa}$ & $16 \mathrm{~b} \& 6$ & 13.32 & 13.30 & 13.34 \\
\hline$\sigma_{\mathrm{s}}$ & $\mathrm{MPa}$ & 29 & 279 & 280 & 282 \\
\hline$\sigma_{\mathrm{p}}$ & $\mathrm{MPa}$ & 30 & 987 & 988 & 989 \\
\hline $\mathrm{g}(\beta)$ & $\mathrm{MN}$ & $26 \mathrm{a}$ & -0.0083 & -0.0014 & +0.0007 \\
\hline $\mathrm{d}$ & $\mathrm{m}$ & 13 & 0.522 & 0.522 & 0.522 \\
\hline$(\beta \mathrm{d})_{\mathrm{i}}$ & $\mathrm{m}$ & $12 \mathrm{a}$ & & 0.202 & \\
\hline
\end{tabular}




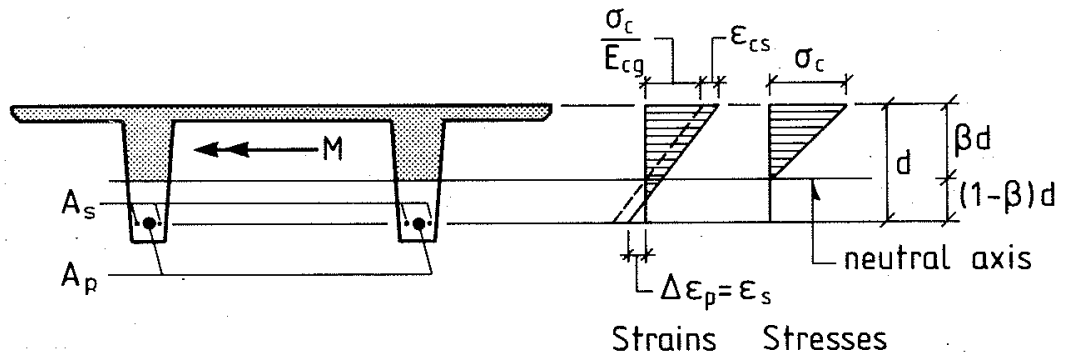

FIG. 1. Cracked Concrete Cross-Section

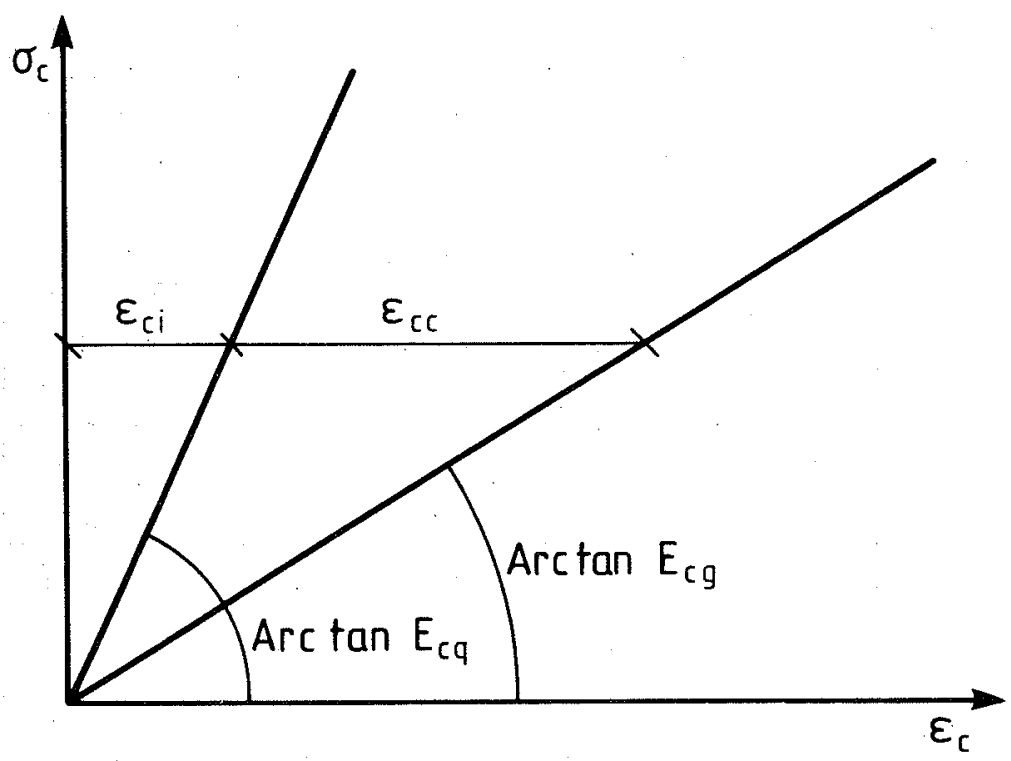

FIG. 2. Stress-Strain Curves for Concrete 


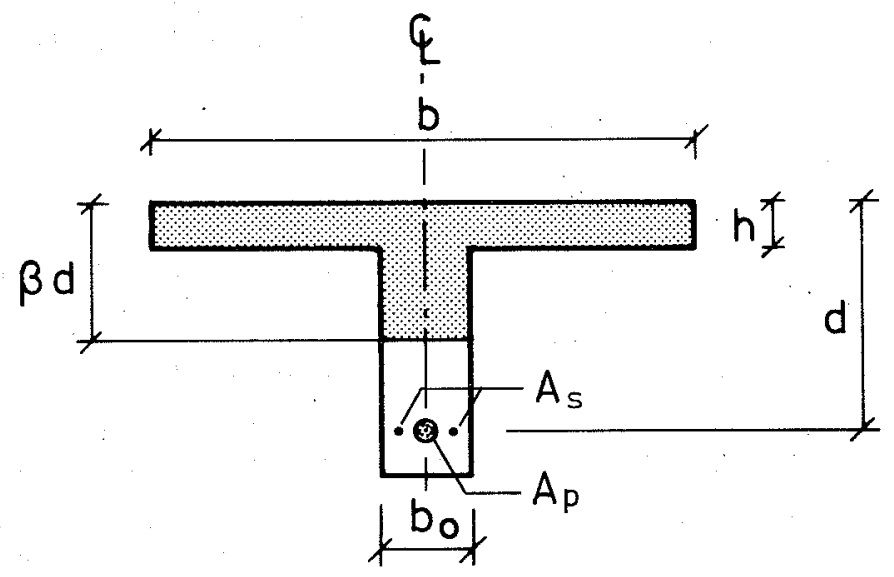

FIG. 3. T-Section

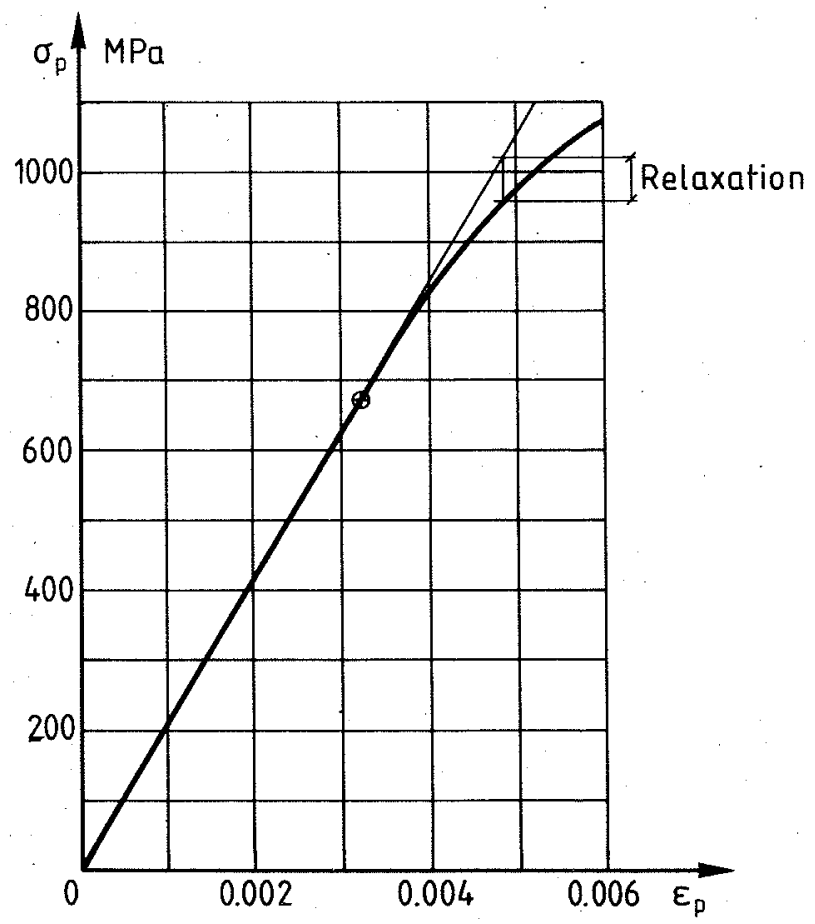

FIG. 4. Stress-Strain Curve for Sustained Strain 
AFDELINGEN FOR BERENDE KONSTRUKTIONER

DANMARKS TEKNISKE HØJSKOLE

Structural Research Laboratory

Technical University of Denmark, DK-2800 Lyngby

RAPPORTER (Reports)

$(1976-\quad)$

R 69. PEDERSEN, MAX ELGAARD: En 2.ordens tilnarmelse til de konstitutive ligninger for beton. 1976.

$R$ 70. RIBERHOLT, HILMER and PETER CHR. NIELSEN: Timber under combined compression and bending stress. 1976.

R 71. KRENCHEL, HERBERT og J. BJøRNBAK-HANSEN : Unders $\emptyset$ gelse af let konstruktionsbetons vasentligste materialeparametre. 1976.

R 72. BRASTRUP, M.W., M.P. NIELSEN, FINN BACH and B. CHR. JENSEN: Shear tests on reinforced concrete $\mathrm{T}$-beams. Series T. 1976.

R 73. NIELSEN, M.P. and M.W. BRESTRUP: Plastic shear strength of reinforced concrete beams. 1976.

R 74. Resume-oversigt 1975. Summaries of papers 1975. 1976.*)

R 75. BRESTRUP, M.N., M.P. NIELSEN, B.CHR. JENSEN and FINN BACH: Axisymmetric punching of plain and reinforced concrete. 1976.

R 76. BRゆNDUM-NIELSEN, TROELS: Partial prestressing. 1976.

R 77. LAURSEN, M.E.: EQSHELL. An equilibrium shell finite element for arbitrary shell geometry. 1977.

$\mathrm{R}$ 78. DYRBYE, CLAES and FIEMMING BLIGAARD PEDERSEN: Rubber mountings and vibration isolation. 1977.

R 79. BRESTRUP, M.W., M.P. NIELSEN and FINN BACH: Rational analysis and design of stirrups in reinforced concrete beams. 1977 .

R 30. ABK's informationsdag 1977. 1977.

R 81. Resumeoversigt 1976. Summaries of papers 1976. 1977.

R 32. MøLLMANN, H.: Static and dynamic analysis of plane cable structures. 1977.

R 83. RIBERHOLT, H.: Bolte indlimet i limtra. 1977.

$R$ 34. AGERSKOV, H. and J. BJøRNBAK-HANSEN: Fatigue strength of welded connections in round bar steel structures. 1977 .

R 85. LAURSEN, M.E., M.P. NIELSEN and M. ROIKJER: Stability analysis of beams and arches by energy methods. 1977 .

R 86. LAURSEN, M.E.: Derivation of symetric integration formulas for triangles. 1977.

R 37 . LAURSEN, M.E.: Stability and vibration analysis of plane curved beams by an equilibrium finite element method. 1977.

$R$ 88. PEDERSEN, FLEMMING BLIGAARD: Vibration analysis of viscoelastically damped sandwich structures. 1978.

R 39. BRDNDUM-NIELSEN, TROELS: Epoxy resin repair of cracked concrete beams. 1978.

R 90. HESS, UNE, B.CHR. JENSEN, M.W. BRFSTRUP, M.P. NIELSEN og FINN BACII: Sennemlokning af jernbetonplader. 1978.

*) Uasolgt. Out of print. 
R 91. HANSEN, KARI ERIK, KAJ L. BRYDER Og M.P. NIELSEN: Armeringsbestemmelse $i$ jernbetonskaller. 1978 .

R 92. ASKEGAARD, V.: Stress and strain measurements in solid materials. 1978.

$\mathrm{R}$ 93. SCHMIDT, HENRIK: Udbredelse af akustisk emission i beton. 1978 .

R 94. BYSKOV, ESBEN Og STEEN KRENK: Konstruktionstrxs mekaniske styrke. 1978.

R 95. Resumeoversigt 1977. Summaries of papers 1977. 1978 .

$R$ 96. DYRBYE, CLÄES: Admittance-curves. ZILSTORFF, ANNE and CLAES DYRBYE: Admittance of bars. 1978.

R 97. DYRBYE, CLAES: Dynamic systems with sinusoidal mode shapes. 1978.

R 98. ANDRESEN, CLAUS: Bjælker og sфjler med åbne, tyndvaggede tværsnit. 1978 .

R 99. RIBERHOLT, H.: Eingeleimte Gewindestangen. 1978.

R 100. PEDERSEN, C.: Opbojet langdearmering sorn forskydningsarmering. 1978 .

R 101. JENSEN, J.F., M.W. BRESTRUP, F. BACH Og M.P. NIELSEN: Nogle plasticitetsteoretiske bjalkeløsninger. 1978.

R 102 . JENSEN, J.F., C. PEDERSEN, M.W. BRSSTRUP, E. BACH og M.P. NIELSEN: Rapport over forskydningsfors $6 \mathrm{~g}$ med 6 spaendbetonbjalker. 1978.

R 103. JENSEN, J.F., V. JENSEN, H.H. CHRISTENSEN, F. BACH, M.W. BRISSTRUP and M.P. NIELSEN: On the behaviour of cracked reinforced concrete beams in the elastic range. 1978 .

R 104. ANDERSEN, ERIK YDING: Konstruktionsovervågning med akustisk emission. Prøvebelastning af landevejsbro. 1979.

R 105. FREDSGAARD, SØDREN SKYTTE: Ligevægtselementer i de nite elementers metode. Formulering og beregningsgang. 1979.

R 106. AGERSKOV, HENNING: Tests on high-strength bolted T-stub. connections. 1979.

R 1C?. KIRK, JENS: Direkte beregning af imperfekte skalkonstruktioner. 1979.

R 108. Resumeoversigt 1978. Summaries of papers 1978. 1979.

$\mathrm{R}$ 109. BR $\varnothing \mathrm{NDUM}-\mathrm{NIELSEN,} \mathrm{TROELS:} \mathrm{Stress} \mathrm{analysis} \mathrm{of} \mathrm{concrete}$ sections under service load. 1979.

Abonnement 1.7.1978 - 1.7.1979 inden for Danmark kr. 40.-. Subscription rate 1.7.1978 - 1.7.1979 D. Kr. 60.- 
